UNIVERSIDADE DE SÃO PAULO

ESCOLA DE EDUCAÇÃO FÍSICA E ESPORTE

\title{
INTEGRAÇÃO DO CONTROLE POSTURAL E DE AÇÕES MANUAIS EM FUNÇÃO DA PREVISIBILIDADE DE PERTURBAÇÃO E DA DEMANDA DE PRECISÃO ESPACIAL
}

Elke dos Santos Lima

SÃO PAULO

2008 